\title{
Penyimpanan Obat dan Bahan Medis Habis Pakai di UPTD Puskesmas Nusa Indah Kota Bengkulu
}

\author{
Dewi Winni Fauziah ${ }^{\mathrm{a}, 1^{*}}$, Panti Yuniarti ${ }^{\mathrm{a}, 2}$, Afni Afriliana Syaputria,3 \\ aD3 Farmasi Stikes Al-Fatah Bengkulu, J1. Indragiri Gang 3 Serangkai, Padang Harapan, Kota Bengkulu, Indonesia. \\ 1dewiwinnifauziah@gmail.com* \\ *korespondensi penulis
}

\begin{tabular}{|c|c|}
\hline INFO ARTIKEL & ABSTRAK \\
\hline $\begin{array}{l}\text { Diterima : } \\
\text { 3I-I2-202I } \\
\text { Direvisi : } \\
\text { 04-0I-2022 } \\
\text { Disetujui: } \\
\text { 04-0I-2022 }\end{array}$ & $\begin{array}{l}\text { Penyimpanan Obat dan Bahan Medis Habis Pakai (BMHP) ialah } \\
\text { kegiatan pengaturan terhadap Obat yang diterima supaya aman (tidak hilang), } \\
\text { terhindar dari kerusakan fisik maupun kimia agar mutunya tetap terjamin dan } \\
\text { sesuai dengan persyaratan yang ditetapkan. Puskesmas yang merupakan } \\
\text { singkatan dari Pusat Kesehatan Masyarakat ialah fasilitas pelayanan kesehatan } \\
\text { guna menyelenggarakan upaya kesehatan masyarakat dan kesehatan } \\
\text { perseorangan di tingkat pertama, serta lebih mengutamakan upaya promotif dan }\end{array}$ \\
\hline $\begin{array}{l}\text { Kata kunci: } \\
\text { Puskesmas; } \\
\text { Penyimpanan Obat; } \\
\text { BMHP; } \\
\text { UPTD. }\end{array}$ & $\begin{array}{l}\text { preventif di wilayah kerjanya. Penelitian ini bertujuan untuk mengamati cara } \\
\text { penyimpanan Obat dan BMHP di Unit Pelaksana Teknis Dinas (UPTD) } \\
\text { Puskesmas Nusa Indah Kota Bengkulu. Pengambilan sampel dalam penelitian } \\
\text { ini menggunakan teknik purposive sampling. Observasi dilakukan terhadap } \\
\text { variabel penyimpanan obat dan BMHP serta variabel gudang penyimpanan obat } \\
\text { dan BMHP di Puskesmas Nusa Indah Bengkulu. Data yang dikumpulkan } \\
\text { merupakan data primer yang diperoleh peneliti melalui observasi di lapangan } \\
\text { secara langsung kemudian dibandingkan dengan standar yang ditetapkan dalam } \\
\text { Permenkes dan Kemenkes. Hasil penelitian menunjukkan bahwa penyimpanan } \\
\text { Obat dan BMHP di gudang dan Apotek UPTD Puskesmas Nusa Indah Kota } \\
\text { Bengkulu telah sesuai dengan Ketentuan yang telah ditetapkan dalam Permenkes } \\
\text { Nomer } 74 \text { Tahun } 2016 \text { dan Kemenkes RI 20I0. }\end{array}$ \\
\hline
\end{tabular}

Key word:

Puskesmas;

Medicine storage;

BMHP;

UPTD.

\section{ABSTRACT}

Medicine storage dan Medical disposable is an activity to regulate the drugs received so that they are safe (not lost), avoid physical and chemical damage so that their quality is guaranteed and in accordance with the stipulated requirements. Puskesmas, which stands for Community Health Center, is a health service facility to carry out public health and individual health efforts at the first level and prioritize promotive and preventive efforts in its working area. The aims of this study are to observe how to store the drugs and BMHP in Unit Pelaksana Teknis Dinas (UPTD) Nusa Indah Public Health Center, Bengkulu. This study uses purposive sampling technique to collect the sample. Observations were made on the drug storage variables and BMHP as well as the drug storage warehouse and BMHP variables at the Nusa Indah Bengkulu Health Center. The data collected is primary data obtained by researchers through direct field observations and then compared with the standards set in the Permenkes and the Kemenkes. The results showed that the storage of drugs and BMHP in warehouses and pharmacies of UPTD Puskesmas Nusa Indah Bengkulu was in accordance with the regulation in the Permenkes Nomer 74 of 2016 and the Kemenkes RI 2010.

This is an open access article under the CC-BY-SA license. 


\section{Pendahuluan}

Pusat Kesehatan Masyarakat (Puskesmas) merupakan fasilitas pelayanan kesehatan yang menyelenggarakan upaya kesehatan masyarakat dan upaya kesehatan perseorangan tingkat pertama, dengan lebih mengutamakan upaya promotif dan preventif di wilayah kerjanya (Permenkes, 2019). Adapun upaya kesehatan yang dilakukan oleh Puskesmas meliputi peningkatan kesehatan (promotif), pencegahan penyakit (preventif), penyembuhan penyakit (kuratif), pemeliharaan dan pemulihan kesehatan (rehabilitas) yang dilaksanakan secara menyeluruh, terpadu dan berkesinambungan (Permenkes, 2019).

Pelayanan kefarmasian merupakan bagian dari pelayanan kesehatan yang ada di Puskesmas. Pemerintah menetapkan standar pelayanan kefarmasian di puskesmas sebagai tolak ukur yang digunakan sebagai pedoman bagi tenaga kefarmasian dalam menyelenggarakan pelayanan kefarmasian yang meliputi pengelolaan Obat dan Bahan Medis Habis Pakai serta pelayanan farmasi klinik seperti pengkajian dan pelayanan resep, pelayanan informasi Obat, dan monitoring efek samping Obat (Permenkes, 2020).

Penyimpanan obat adalah suatu kegiatan pengamanan dengan cara menempatkan obat-obatan yang diterima pada tempat yang dinilai aman, dimana kegiatan penyimpanan disini mencakup tiga faktor yaitu pengaturan tata ruang dan penyusunan stok obat, pengamanan mutu obat, serta pencatatan stok obat. Fungsi dari penyimpanan obat di Puskesmas antara lain pemeliharaan mutu obat, menjamin ketersediaan obat, serta memudahkan pencarian dan pengawasan. (Anonim, 2010).

Penyimpanan Obat dan Bahan Medis Habis Pakai merupakan suatu kegiatan pengaturan terhadap Obat yang diterima agar aman (tidak hilang), terhindar dari kerusakan fisik maupun kimia dan mutunya tetap terjamin, sesuai dengan persyaratan yang ditetapkan (Permenkes, 2019). Kondisi penyimpanan untuk setiap item obat dan Bahan Medis Habis Pakai berbeda, dimana penyimpanan yang baik untuk satu obat dan Bahan Medis Habis Pakai belum tentu baik untuk obat lain. Penyimpanan yang baik dan benar akan memudahkan pengambilan obat dan Bahan Medis Habis Pakai dan juga dapat mempertahankan mutu dan stabilitas obat (Sudarti, 2018).

Penyimpanan obat dan Bahan Medis Habis Pakai mempengaruhi kestabilan dari obat dan Bahan Medis Habis Pakai. Penyimpanan obat pada suhu udara panas, kelembaban udara yang tinggi dan terpapar cahaya dapat merusak mutu obat dan Bahan Medis Habis Pakai (Sudarti, 2018).
Hasil penelitian Wardhana (2013) tentang profil penyimpanan obat di puskesmas pada dua kecamatan yang berbeda di Kota Kediri, menyebutkan bahwa tata cara penyimpanan obat dan kondisi penyimpanan obat masih belum memenuhi beberapa parameter yang dipersyaratkan oleh Depkes, 2008 antara lain meliputi: Penerapan sistem First Expired First Out (FEFO) dan First In First Out (FIFO), Golongan antibiotik harus disimpan dalam wadah tertutup rapat, disimpan ditempat kering, vaksin dan serum harus dalam wadah tertutup rapat, terhindar dari cahaya dan disimpan dalam lemari pendingin (suhu $4-8^{\circ} \mathrm{C}$ ), obat injeksi disimpan dalam tempat yang terhindar dari cahaya matahari langsung, tablet salut disimpan dalam wadah tertutup rapat dan pengambilannya menggunakan sendok, untuk obat dengan waktu kadaluwarsa yang sudah dekat diberi tanda khusus, misalnya dengan menuliskan waktu kadaluwarsa pada dus menggunakan spidol.

Hasil penelitian Khoirurrizza,dkk (2017) tentang analisis proses penyimpanan obat di puskesmas teling atas kecamatan wanea kota manado, di dapatkan bahwa gudang obat Puskesmas Teling Atas hanya berukuran $2 \times 3 \mathrm{~m}^{2}$, tidak sesuai dengan Kemenkes, 2010 .

UPTD Puskesmas Nusa Indah merupakan salah satu pelayanan kesehatan di Kota Bengkuluyang melakukan penyimpanan sediaan farmasi dan Bahan Medis Habis Pakai yang belum pernah dilakukan penelitian mengenai sistem penyimpanan obat dan Bahan Medis Habis Pakai. Berdasarkan dari latar belakang diatas maka peneliti tertarik untuk melakukan penelitian di UPTD Puskesmas Nusa Indah Kota Bengkuluuntuk melihat kesesuaian penerapan standar penyimpanan obat dan Bahan Medis Habis Pakai untuk mencapai sistem penyimpanan yang baik dan efektif.

\section{Metode}

\section{Tempat dan Waktu Penelitian}

Penelitian dilakukan di UPTD Puskesmas Nusa Indah Kota Bengkulu bulan Juni 202I.

\section{Populasi dan Sampel Populasi}

Populasi dalam penelitian ini yaitu seluruh penyimpanan obat, kondisi gudang penyimpanan Obat dan Bahan Medis Habis Pakai di UPTD Puskesmas Nusa Indah Kota Bengkulu.

\section{Sampel}

Pengambilan Sampel dalam penelitian ini dilakukan dengan Teknik Purposive Sampling yaitu suatu teknik non random sampling dimana 
menentukan pengambilan sampel dengan menetapkan ciri-ciri khusus sesuai dengan tujuan penelitian (Sugiono, 2017). Sampel yang di teliti harus memiliki kriteria sebagai berikut:

\section{Kriteria Inklusi}

a. Semua sediaan Obat dan Bahan Medis Habis Pakai di UPTD Puskesmas Nusa Indah Kota Bengkulu.

b. Kondisi Gudang di UPTD Puskesmas Nusa Indah Bengkulu.

c.

\section{Kriteria Ekslusi}

a. Bahan Medis yang bukan termasuk alat kesehatan yang ditunjukkan untuk penggunaan sekali pakai.

\section{Hasil Dan Pembahasan}

Penelitian dengan judul Penyimpanan Obat dan Bahan Medis Habis Pakai di UPTD Puskesmas Nusa Indah Kota Bengkulu yang dilakukan pada bulan Juni 202I, dengan cara melakukan observasi dan diperoleh hasil :

Dari variabel bentuk dan jenis sediaan dengan indikator yang ada, didapatkan hasil yaitu sudah sesuai begitu juga dengan variabel narkotika dan psikotropika sudah sesuai dengan Permenkes dan bisa dilihat pada tabel I.

Tabel I. Lembar Observasi Penyimpanan Obat dan Bahan Medis Habis Pakai (BMHP)

\begin{tabular}{|c|c|c|c|c|}
\hline \multirow[b]{2}{*}{ No. } & \multirow[b]{2}{*}{ Variabel } & \multirow[b]{2}{*}{ Indikator Penilaian } & \multicolumn{2}{|c|}{ HASIL } \\
\hline & & & SESUAI & TIDAK \\
\hline \multirow[t]{6}{*}{ I } & $\begin{array}{l}\text { Bentuk dan Jenis } \\
\text { Sediaan }\end{array}$ & $\begin{array}{l}\text { I) Obat dan Bahan Medis Habis Pakai disusun } \\
\text { secara alfabetis untuk setiap bentuk sediaan }\end{array}$ & SESUAI & \\
\hline & & $\begin{array}{l}\text { 2) Menggunakan prinsip FEFO dan FIFO } \\
\text { yang lebih awal mendekati kadaluwarsa dan } \\
\text { yang pertama kali datang dikeluarkan dahulu }\end{array}$ & SESUAI & \\
\hline & & $\begin{array}{l}\text { 3) Sediaan obat dalam dan obat luar } \\
\text { dipisahkan }\end{array}$ & SESUAI & \\
\hline & & $\begin{array}{l}\text { 4) Ada kartu stok untuk masing-masing item } \\
\text { obat dan Bahan Medis Habis Pakai }\end{array}$ & SESUAI & \\
\hline & & $\begin{array}{l}\text { 5) Obat yang membutuhkan suhu dingin } \\
\text { disimpan di kulkas }\end{array}$ & SESUAI & \\
\hline & & $\begin{array}{l}\text { 6) Cairan yang berukuran besar diletakkan di } \\
\text { rak bagian bawah }\end{array}$ & SESUAI & \\
\hline \multirow[t]{3}{*}{2.} & $\begin{array}{l}\text { Narkotika dan } \\
\text { Psikotropika }\end{array}$ & $\begin{array}{l}\text { L) Lemari Nakotika dan Psikotropika } \\
\text { mempunyai ukuran } 40 \times 80 \times 100 \mathrm{~cm}\end{array}$ & SESUAI & \\
\hline & & $\begin{array}{l}\text { 2) Mempunyai } 2 \text { (dua) buah kunci yang } \\
\text { berbeda }\end{array}$ & SESUAI & \\
\hline & & 3) Terbuat dari bahan yang kuat & SESUAI & \\
\hline
\end{tabular}

Dari variabel gudang penyimpanan dengan indikator yang ada, didapatkan hasil yaitu masih ada yang belum sesuai dengan Kemenkes dan bisa dilihat pada tabel di bawah:

Tabel 2. Lembar Observasi Gudang Penyimpanan

\begin{tabular}{|c|c|c|c|c|}
\hline \multirow{2}{*}{ No } & \multirow{2}{*}{ Variabel } & \multirow{2}{*}{ Indikator Penilaian } & \multicolumn{2}{|c|}{ HASIL } \\
\hline & & & SESUAI & TIDAK \\
\hline \multirow[t]{9}{*}{ I } & \multirow[t]{9}{*}{$\begin{array}{l}\text { Gudang } \\
\text { Penyimpanan }\end{array}$} & $\begin{array}{l}\text { I) Luas gudang minimal } 3 \times 4 \text { meter dan atau disesuaikan dengan jumlah obat } \\
\text { dan Bahan Medis Habis Pakai yang disimpan }\end{array}$ & SESUAI & \\
\hline & & 2) Ruangan kering tidak lembab & SESUAI & \\
\hline & & $\begin{array}{l}\text { 3) Adanya ventilasi untuk keluar masuk aliran udara (jika tidak terdapat } \\
\text { AC/kipas angin) }\end{array}$ & SESUAI & \\
\hline & & 4) Adanya jendela, memiliki teralis, dan memiliki pelindung & SESUAI & \\
\hline & & $\begin{array}{l}\text { 5) Jendela dicat putih atau mempunyai gorden, jendela aman dan mempunyai } \\
\text { trali }\end{array}$ & & TIDAK \\
\hline & & 6) Lantai dibuat dari semen/ tegel/ keramik, dan dalam keadaan bersih & SESUAI & \\
\hline & & 7) Adanya pallet untuk meletakan kardus besar & SESUAI & \\
\hline & & $\begin{array}{l}\text { 8) Adanya lemari untuk narkotika dan psikotropika yang memiliki } 2 \text { lapis } \\
\text { pintu yang masing-masing terkunci dan tidak bisa dibawa kemana-mana }\end{array}$ & SESUAI & \\
\hline & & 9) Lemari pendingin dalam keadaan baik, tidak ada makanan di dalam & SESUAI & \\
\hline
\end{tabular}


I0) Gudang memiliki 2 pintu ganda, pintu teralis dan kayu yang masing-masing SESUA memiliki kunci

II) Tersedia alat pengukur suhu

SESUAI

\section{Pembahasan}

Dalam melakukan proses penyimpanan banyak hal-hal yang harus diperhatikan agar mutu obat dapat terjamin, diantaranya pengaturan tata ruang penyimpanan dengan tujuan untuk mendapatkan kemudahan dalam penyimpanan, penyusunan, pencarian dan pengawasan obat-obatan. Sirkulasi udara yang baik juga menjadi salah satu faktor penting dalam merancang gudang tujuannya adalah untuk memaksimalkan umur hidup dari obat sekaligus bermanfaat dalam memperpanjang dan memperbaiki kondisi kerja, bila perlu gudang obat harus dilengkapi dengan AC/kipas angin serta ventilasi yang mencukupi (Depkes RI, 2007).

Gudang juga harus dilengkapi dengan rak atau pallet untuk tempat penyimpanan obat, thermometer, alat pemadam kebakaran, penerangan yang cukup, lemari khusus untuk psikotropika dan narkotika serta lemari pendingin untuk menyimpan vaksin untuk menjaga mutu obat. Selain itu ukuran luas gudang juga harus memenuhi standar yang ada agar semua obat dapat disimpan di dalam gudang (Depkes RI, 2007).

Pada penelitian ini dilakukan suatu observasi tentang penyimpanan obat dan Bahan Medis Habis Pakai di UPTD Puskesmas Nusa Indah Kota Bengkulu. Observasi dilakukan di Gudang Obat dan Apotek atau Kamar Obat.

Penyimpanan Obat dan Bahan Medis Habis Pakai merupakan suatu kegiatan pengaturan terhadap Obat yang diterima agar aman (tidak hilang), terhindar dari kerusakan fisik maupun kimia dan mutunya tetap terjamin, sesuai dengan persyaratan yang ditetapkan (Permenkes, 2019).

Pada penelitian ini dilakukan observasi menggunakan variabel penyimpanan obat dan Bahan Medis Habis Pakai, dengan indikator, bentuk dan jenis sediaan, Narkotika dan Psikotropika. Kemudian variabel gudang penyimpanan obat dan Bahan Medis Habis Pakai dengan indikator, gudang penyimpanan.

Pada indikator bentuk dan jenis sediaan yang di observasi yaitu Obat dan Bahan Medis Habis Pakai disusun secara alfabetis untuk setiap bentuk sediaan, menggunakan sistem FIFO dan FEFO pada UPTD Puskesmas Nusa Indah penyusunan nya sudah sesuai. Sediaan obat dalam dan obat luar dipisah. Masing-masing item obat dan Bahan Medis Habis Pakai sudah mempunyai kartu stok yang terisi sesuai masuk dan keluarnya obat dan Bahan Medis Habis Pakai. Obat yang membutuhkan suhu dingin sudah di simpan di dalam lemari es sesuai dengan suhu yang tertera pada kemasan. Cairan yang berukuran besar diletakkan di bagian bawah. Hasil penelitian ini menunjukkan hasil yang serupa dengan penelitian sebelumnya yang dilakukan oleh Sheina, dkk (2010) dimana penyimpanan Obat di Gudang Instalasi Farmasi RS PKU Muhammadiyyah Yogyakarta juga menerapkan system FIFO dan FEFO, penggolongan berdasarkan abjad, serta penggolongan berdasarkan bentuk sediaan. Penyimpanan Obat dan BMHP yang tidak baik serta tidak sesuai dengan standart akan berdampak pada menurunnya kualitas mutu persediaan, serta sulitnya dalam management stok persediaan Obat, baik di Apotek maunpun di Gudang.

Pada indiktor Narkotika dan Psikotropika yang di observasi yaitu Lemari Narkotika dan Psikotropika mempunyai ukuran $40 \times 80 \times 100 \mathrm{~cm}$, untuk UPTD Puskesmas Nusa Indah sendiri sudah memenuhi persyaratan yaitu berukuran 40 x 80 x $100 \mathrm{~cm}$ sesuai dengan Permenkes, 2016. Mempunyai 2 (dua) buah kunci yang berbeda terbuat dari bahan yang kuat. Hasil tersebut serupa dengan penelitian Sheina, dkk (2010) bahwa penyimpanan Narkotika dan Psikotropika di RS PKU Muhammadiyyah Yogyakarta sudah sesuai dengan SOP yakni memiliki lemari khusus dengan spesifikasi yang sesuai dengan persyaratan standart. Lemari penyimpanan Narkotika dan Psikotropika wajib memenuhi persayaratan standar sehingga dapat menjamin keamanan persediaan Obat yang tersimpan di dalamnya.

Pada indikator gudang penyimpanan yang di observasi yaitu Luas gudang minimal 3 x 4 meter dan atau disesuaikan dengan jumlah obat dan BMHP yang disimpan, UPTD Puskesmas Nusa Indah memiliki luas $3 \times 3$ meter dan untuk gudang nya sendiri kering tidak lembab. Mempunyai ventilasi yang di beri teralis dan terdapat AC di dalam gudang yang selalu hidup $24 \mathrm{jam}$. Gudang UPTD Puskesmas Nusa Indah tidak memiliki jendela tetapi itu tidak berdampak kepada obat dan bahan medis yang ada di gudang karena sudah terdapat AC untuk udara dan lampu sebagai pencahayaan, namun bila saat mati lampu jendela berguna untuk mengatur udara dan pencahayaan. Lantai sudah dibuat dari keramik dan dalam keadaan bersih, tidak licin. Adanya pallet untuk meletakkan kardus yang masih memiliki isi sehingga tidak merusak obat dan Bahan Medis Habis Pakai. Luas Gudang juga tidak mencapai 3x4m, namun stok perbekalan yang tersimpan juga tidak banyak sehingga luas tersebut masih dinilai memadai untuk menyimpan perbekalan yang ada di Puskesmas 
Nusa Indah. Terdapat lemari Narkotika dan Psikotropika di gudang, yang tergantung pada tembok, memiliki 2 pintu ganda serta kunci yang berbeda untuk setiap pintunya. Adanya lemari pendingin di gudang dengan keadaan baik, tidak ada makanan hanya untuk menyimpan obat. Gudang memiliki 2 pintu ganda, pintu teralis dan kayu yang masing-masing memiliki kunci dan hanya boleh dimasukki oleh orang gudang. Adanya alat ukur suhu di gudang dan lemari pendingin untuk mengontrol suhu sehingga tetap menjaga kualitas obat dan Bahan Medis Habis Pakai tetap dalam keadaan baik. Hasil penelitian ini serupa dengan penelitian Sheina, dkk (2010) dimana luas Gudang yang terdapat pada Instalasi Farmasi RS PKU Muhammadiyyah Yogayakarta masih dinilai kurang memadai dikarenakan stok obat yang melimpah, namun samasama sudah memiliki alat pengukur suhu dan kelembaban. Gudang penyimpanan yang tidak sesuai standart dapat berdampak pada penurunan mutu persediaan Obat dan BMHP serta berdampak juga pada menurunnya performa pelayanan kepada pasien seperti yang diungkapkan oleh Wijana, dkk (2020) dalam penelitian yang telah dilakukannya.

Untuk suhu pada lemari pendingin sewaktu memiliki suhu $5^{\circ} \mathrm{C}$, sedangkan suhu rata-rata bulan Juni adalah $3,8^{\circ} \mathrm{C}$ berdasarkan buku Farmakope Indonesia edisi $\mathrm{V}$ yaitu untuk lemari es berkisar dari $2-8^{\circ} \mathrm{C}$. Sedangkan untuk suhu gudang sewaktu $20^{\circ} \mathrm{c}$, sedangkan suhu rata-rata bulan Juni adalah I6,9 berdasarkan Farmakope Indonesia edisi V yaitu dari $\mathrm{I} 5-30{ }^{\circ} \mathrm{C}$ Suhu lemari pendingin harus sesuai standart agar menjamin mutu Obat yang tersimpan didalamnya tetap memenuhi persyaratan mutu yang baik.

Berdasarkan hasil penelitian di UPTD Puskesmas Nusa Indah Kota Bengkulu, penyimpanan obat dan Bahan Medis Habis Pakai yang ada di gudang dan apotek UPTD Puskesmas Nusa Indah Kota Bengkulu sesuai dengan Permenkes No 74 Tahun 2016 tetang Standar Pelayanan Kefarmasian di Puskesmas dan Kemenkes RI 2010 tentang Materi Pelatihan Manajemen Kefarmasian di Puskesmas. Simpulan

Berdasarkan hasil penelitian di UPTD Puskesmas Nusa Indah Kota Bengkulu, dapat disimpulkan bahwa penyimpanan obat dan Bahan Medis Habis Pakai yang ada di gudang dan apotek UPTD Puskesmas Nusa Indah Kota Bengkulu yang terdiri dari indikator bentuk dan jenis sediaan, narkotika dan psikotropika serta gudang penyimpanan sudah sesuai dengan Permenkes No 74 Tahun 2016 tentang Standar Pelayanan Kefarmasian di Puskesmas dan Kemenkes RI 2010 tentang Materi Pelatihan Manajemen Kefarmasian di Puskesmas, hanya saja untuk perlengkapan alat yaitu AC harus lebih di optimalkan. Luas gudang sudah sesuai dengan Kemenkes dimana luas gudang minimal yaitu $3 \times 4 \mathrm{~cm}$ atau disesuaikan dengan jumlah obat dan Bahan Medis Habis Pakai yang disimpan.

\section{Ucapan Terimakasih}

Instansi UPTD Puskesmas Nusa Indah Kota Bengkulu

\section{Daftar Pustaka}

Anonim. (2010). Materi Pelatihan Manajemen Kefarmasian di Puskesmas. Jakarta: Departemen Kesehatan Republik Indonesia.

Kementrian Kesehatan, R. I. (2010). Materi Pelatihan Manajemen Kefarmasian di Puskesmass. Jakarta: Kemenkes.

Departemen Kesehatan. (2008). Pedoman Pelayanan Kefarmasian di Puskesmas. Jakarta: Depkes.

Departemen Kesehatan. (2007). Pedoman Pengelolaan Obat Publik dan Perbekalan Kesehatan di Daerah Kepulauan. Jakarta: Depkes.

Khoirurrizza, M. M. (2017). Analisis Proses Penyimpanan Obat Di Puskesmas Teling Atas Kecamatan Wanea Kota Manado. Manado.

Peraturan Menteri Kesehatan, R. I. (2016). Peraturan Menteri Kesehatan Republik Indonesia No 74 Tahun 2016 tentang Standar Pelayanan Kefarmasian di Puskesmas. 53(9), I-48.

Peraturan Menteri Kesehatan, R. I. (20I4). Peraturan Menteri Kesehatan Republik Indonesia Nomor 30 Tahun 2014 Tentang Standar Pelayanan Kefarmasiaan di Puskesmas. Jakarta.

Peraturan Menteri Kesehatan, R. I.(2019). Peraturan Menteri Kesehatan No 43 Tahun 2019 Tentang Pusat Kesehatan Masyarakat. Jakarta.

Peraturan Menteri Kesehatan, R. I.(2020). Peraturan Menteri Kesehatan No 26 Tahun 2020

Tentang Standar Pelayanan Kefarmasian di Puskesmas. Jakarta

Sheina, Baby., M.R. Umam., dan Solikhah. (2020). Penyimpanan Obat di Gudang Instalasi Farmasi RS PKU Muhammadiyyah Yogyakarta Unit I. Kes Mas Vol.4 No. I ISSN 1978-0575. Yogyakarta.

Sudarti, H. M. (2018). Sistem Penyimpanan Obat Dan Bahan Medis Habis Pakai (BMHP) Pada Puskesmas Waingapu Yang Terdapat di Wilayah Waingapu Kabupaten Sumba 
Timur. Sumba Timur: Poltekkes Kemenkes Kupang.

Sugiono. (2017). Metode Penelitian Pendidikan. Bandung: Alfabeta.

Wardhana, Z. P. (2013). Profil Penyimpanan Obat Di Puskesmas pada Dua Kecamatan yang berbeda di Kota Kedari. Surabaya: Fakultas Farmasi Univesitas Surabaya.

Wijana, I, Ketut., Fitri, Eka, Sari dan Nurul, Aryaastuti. (2020). "Analisis Penyimpanan Obat di Puskesmas Rejo Katon Kecamatan Raman Utara Kabupaten Lampung Timur”. Jurnal Dunia Kesmas vol.9 No.2. Lampung Timur 